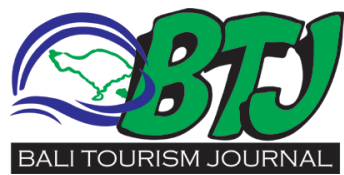

\title{
2020 Bali's Coral Conservation: from pandemic challenge to Government coral garden project
}

\author{
Ida Bagus Agung Wicaksana
}

\section{ABSTRACT}

Bali's coral reef restoration has been the topmost priority by the Indonesian Government and marine activists to save marine habitat in the long run. The action is necessary to halt severe damage that occurs in aquatic habitat over the years. The most apparent threat that has been faced is coral bleaching. Bali's water's tourism activities have sharply dipped between early to mid-2020, yet it did not stop the coral bleaching phenomenon. The phenomenon is occurring due to water temperature rise. The Government's decision to restrict public activity made the conservation task impossible to be done. Albeit challenges in coral conservation became a daunting task in 2020, pleasant news also came from the central Government. Coordinating Minister for Maritime Affairs and Investment Luhut Binsar Pandjaitan revealed the central Government had compiled a
National Economic Recovery (PEN) program for Indonesia Coral Reef Garden (ICRG) Bali. The program is coral reef restoration activities centered in Nusa Dua and several other areas such as Sanur, Serangan, Pandawa Beach, and Buleleng. The coral reef garden will be built using the Ministry of Marine Affairs and Fisheries National Economic Recovery fund worth IDR 111.2 billion. The fund will be used to build a 50 hectares coral plantation. Meanwhile, the Governor of Bali, I Wayan Koster, expressed his appreciation toward the program. Koster believed the program would significantly impact the community, especially in supporting economic recovery since the national economic recovery activities will involve more than 11,000 workers.
'Wicaksana Contractor agungwicaksana12@gmail.com

\section{Editor:}

Ida Bagus Ngurah Tri Pramana
Received : 2020-07-01 Accepted : 2020-08-25 Published: 2020-09-10

Keyword: Conservation, Coral Bleaching, ICRG

Cite This Article: Wicaksana, I.B.A. 2020 Bali's Coral Conservation: from pandemic challenge to Government coral garden project. Bali Tourism Journal (BTJ) 2020, 4(1): 35-39. D0I : 10.36675/btj.v4i1.46

\section{BACKGROUND}

Bali's coral reef restoration has been the topmost priority by the Indonesian Government and marine activists to save marine habitat in the long run. The action is necessary to halt severe damage that occurs in aquatic habitat over the years. The most apparent threat that has been faced is coral bleaching. ${ }^{1,2}$ The bleaching process is detrimental, caused by many factors, such as seawater temperature, pollution, natural disasters, or river sedimentation. ${ }^{3}$ To minimize the damaging coral process, marine activists conduct routine observations and surveillance to map coral reefs condition in several spots of Bali's waters. A significant decline in Bali's tourism activities due to the COVID-19 pandemic had a mixed impact on the island's marine life. Over the years, rapid growth in the island tourism industry has been considered the primary cause of environmental damage for both land and marine habitat. Drastic reduction in marine activity is believed to let the aquatic environment breathe for a while. Although human activities on the water have been dipped between early to mid-2020, the bleaching process keeps occurring due to water temperature rise. The monitoring activities also faced a severe challenge. The recent finding showed that the Government's appeal for social and activity restrictions made conservation tasks impossible to be done. ${ }^{4}$

\section{CORAL REEFS AND ITS SIGNIFICANCE}

Thousands of small animals called Polyps form Coral reef colonies. Coral reefs then act as habitat for various marine plants, animals, and other unknown microorganisms' species. Commonly, coral animals encompass the type of phylum Cnidaria class Anthozoa with tentacles that live in symbiosis with algae called zooxanthellae. In its simplest form, coral reefs consist of a single polyp that resembles a tube, with a mouth located at the top and surrounded by tentacles. ${ }^{6}$ However, in most species, one individual coral polyp will develop into many individuals called colonies. ${ }^{7}$ These animals have unique shapes and various colors. They contribute to producing calcium carbonate (CaCO3), which becomes a significant building block for most marine creatures. ${ }^{8}$

Coral reefs are abundant in Indonesian water since the area is part of the Coral Triangle, an imaginary triangle area rich in aquatic biodiversity. The region covers six countries, namely Indonesia, Malaysia, Papua New Guinea, Philippine, Solomon 
Islands, and Timor Leste. These six countries' areas cover 1.5 percent of the world's ocean and become home to 76 percent or 603 species of total coral reefs. Furthermore, its 37 percent area is habitat for 2,228 coral reef fishes. ${ }^{9}$

Indonesia is home to about $1 / 8$ of the world's coral reefs. The country has the most diverse marine life compared to its neighboring countries in Southeast Asia. ${ }^{10}$ The most extensive and richest coral reefs in terms of the number of corals, fishes, and mollusks' species stretch along the Indo-Pacific region. The area encompasses Indonesia, Polynesia, Australia, then the western part of the Pacific Ocean to East Africa. ${ }^{11}$ Coral reefs become primary components of coastal and marine resources, beside mangrove forests and seaweed beds. The estimated coral reefs area in Indonesian waters is more than $60,000 \mathrm{~km} 2$, widely distributed from the Western

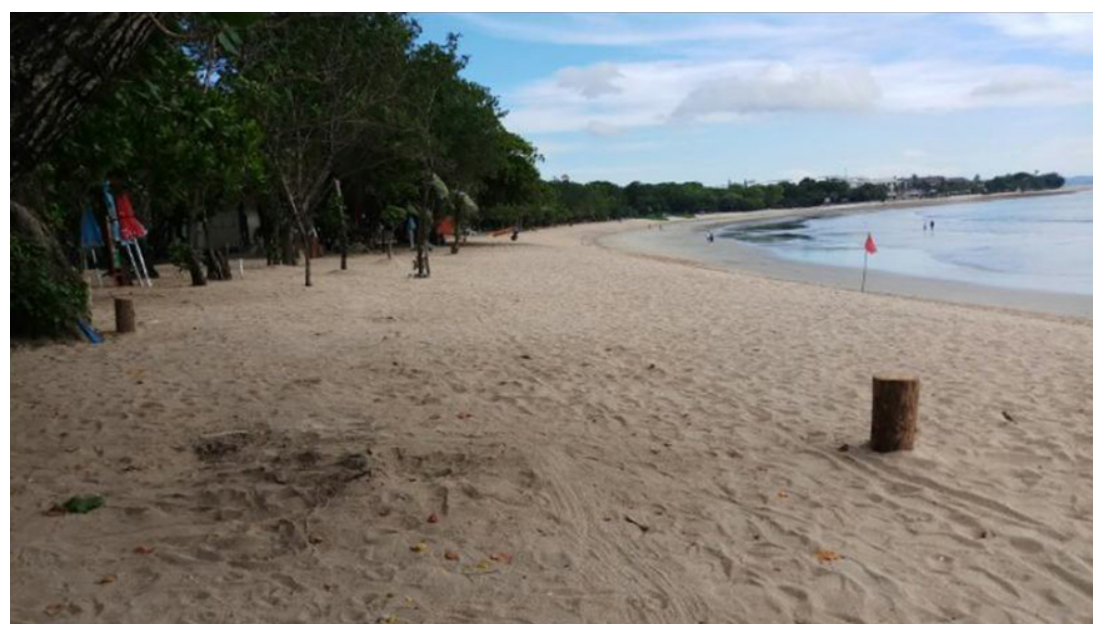

Figure 1. A significant decline in Bali's tourism activities due to the COVID-19 pandemic had a mixed impact on the island's marine life. ${ }^{5}$

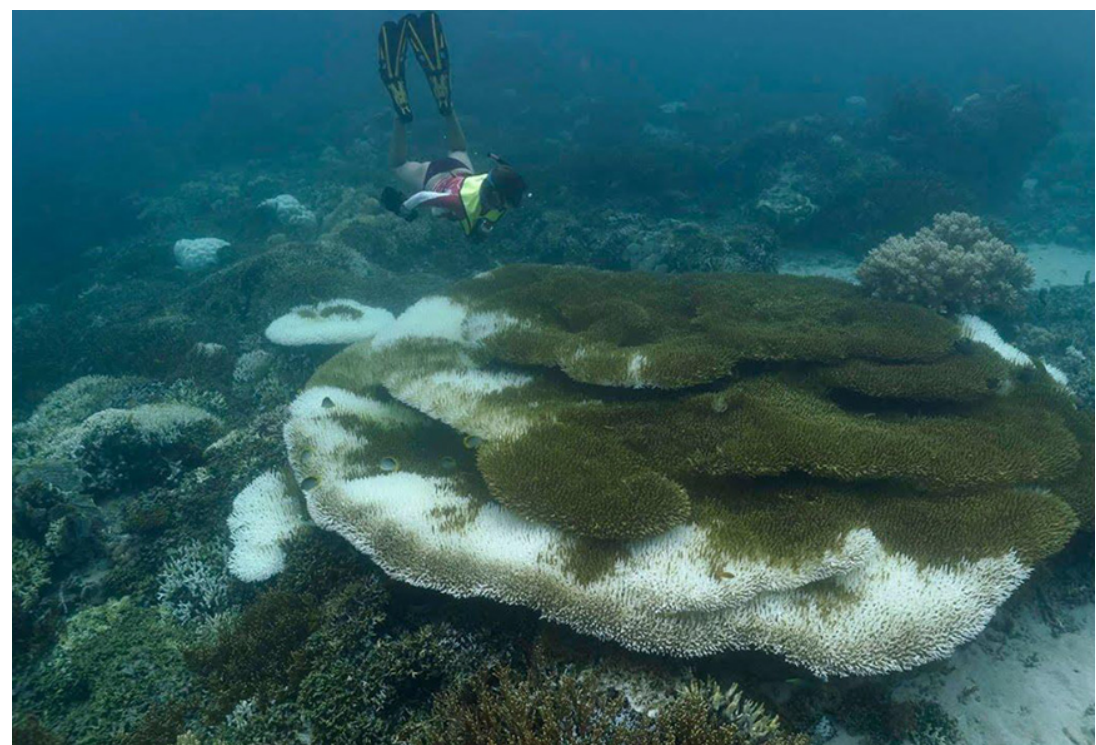

Figure 2. A Documented image of Bleaching Corals ${ }^{14}$
Indonesian Region to the Eastern Indonesian region. ${ }^{10}$ Meanwhile, in Bali, according to data obtained in the journal Status of Indonesia's Coral Reef 2017 and published by the Indonesian Institute of Sciences (LIPI), the area of coral reefs reaches 88 thousand hectares. ${ }^{12}$

\section{FIGHT AGAINST CORAL BLEACHING}

Regarding the coral reefs' condition, The Bali Marine and Fisheries Office noted that only $55 \%$ of the corals are in good quality. In comparison, $30 \%$ is in poor condition, and $20 \%$ is worrying. Besides, the Ocean Health Index showed waters quality in Bali only scored 51 out of 100 . The given score resulted from many threats prone to damage coral habitats such as big waves, global warming, ship or anchor collisions, fish bombing, and vandalism. Therefore, the monitoring process and conservation efforts are carried out regularly to maintain life sustainability in Bali's water. ${ }^{13}$

As for the coral bleaching, according to the Coral Triangle Center (CTC), the Bleaching phenomenon occurs in numerous coral reef spots around Bali. The rising seawater temperature is the culprit behind the bleaching phenomenon. Should the phenomenon neglected, it will result in dying coral widespread. It is feared that the bleaching will expand along with the increase in water temperature. ${ }^{2}$ The hypothesis was supported by a warning from the NOAA satellite, informing an increase in Indonesia's sea water temperature, including Bali has reached temperature between 28-30 degrees Celsius. ${ }^{15}$ The southern Bali region is the most affected area. The areas including Sanur, Serangan, and Nusa Dua. The areas have been home for Porites, Montipora, and several corals types on the average depth of four to six meters. ${ }^{2}$ Although coral bleaching has been occurring in many parts, until 2018, only coral reefs in Nusa Penida, Klungkung with 20,000 hectares, are considered conservation areas. By 2020, Bali is targeting fifty-five thousand hectares more will be added to the conservation list. Five thousand six hundred hectares stretch in Karangasem waters. Then it extends to Denpasar waters in Serangan and Badung, as well as Nusa Penida, to a total conservation area of fifty-five thousand hectares throughout Bali by 2020. ${ }^{13}$

The COVID-19 pandemic left the Bali tourism industry, including marine and diving tourism, untouched from March to September 2020. On the positive side, marine activists believed it lets marine biota and coral reefs grow without disturbance despite no official release regarding coral reefs growth during the COVID-19 pandemic. Diving activities were prohibited to prevent COVID-19 
spread. As a comparison, before the COVID-19 pandemic, especially on the holiday season, several diving spots such as the USAT Liberty shipwreck in Tulamben, Karangasem, may be visited by 300 divers per day. Conservation of coral reefs faces two challenges during the COVID-19 pandemic:

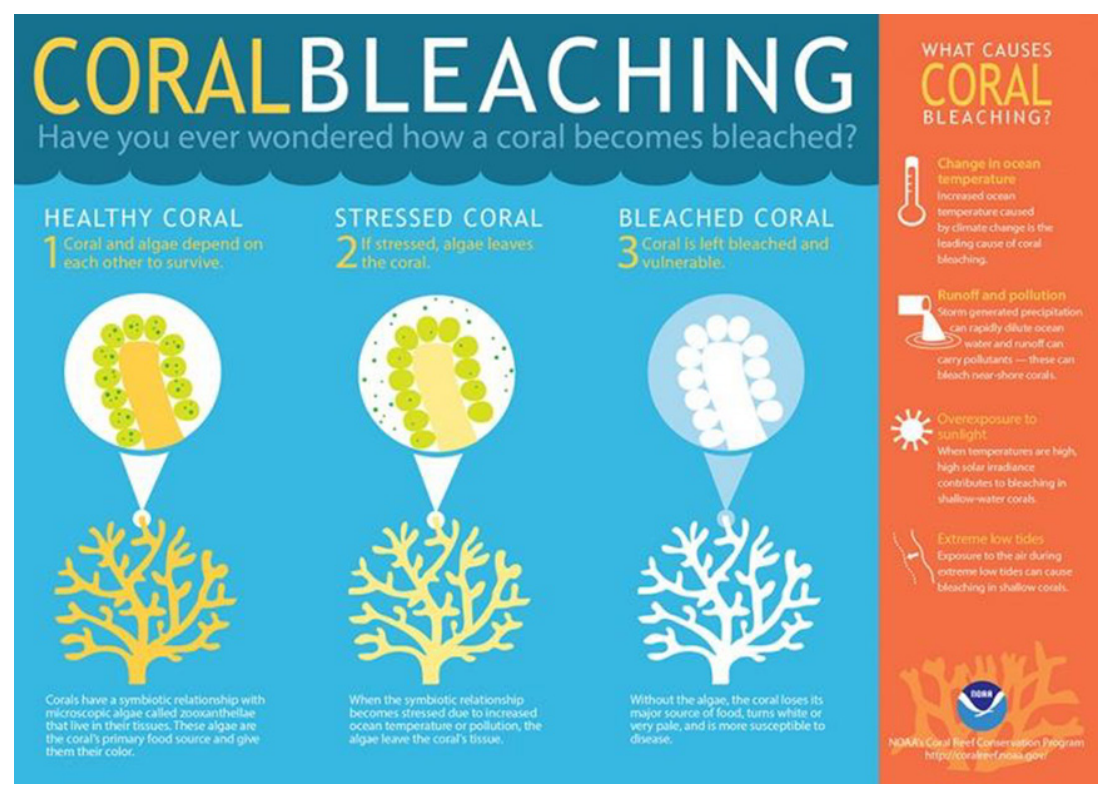

Figure 3. An Infographic depicting information about Coral Bleaching ${ }^{17}$

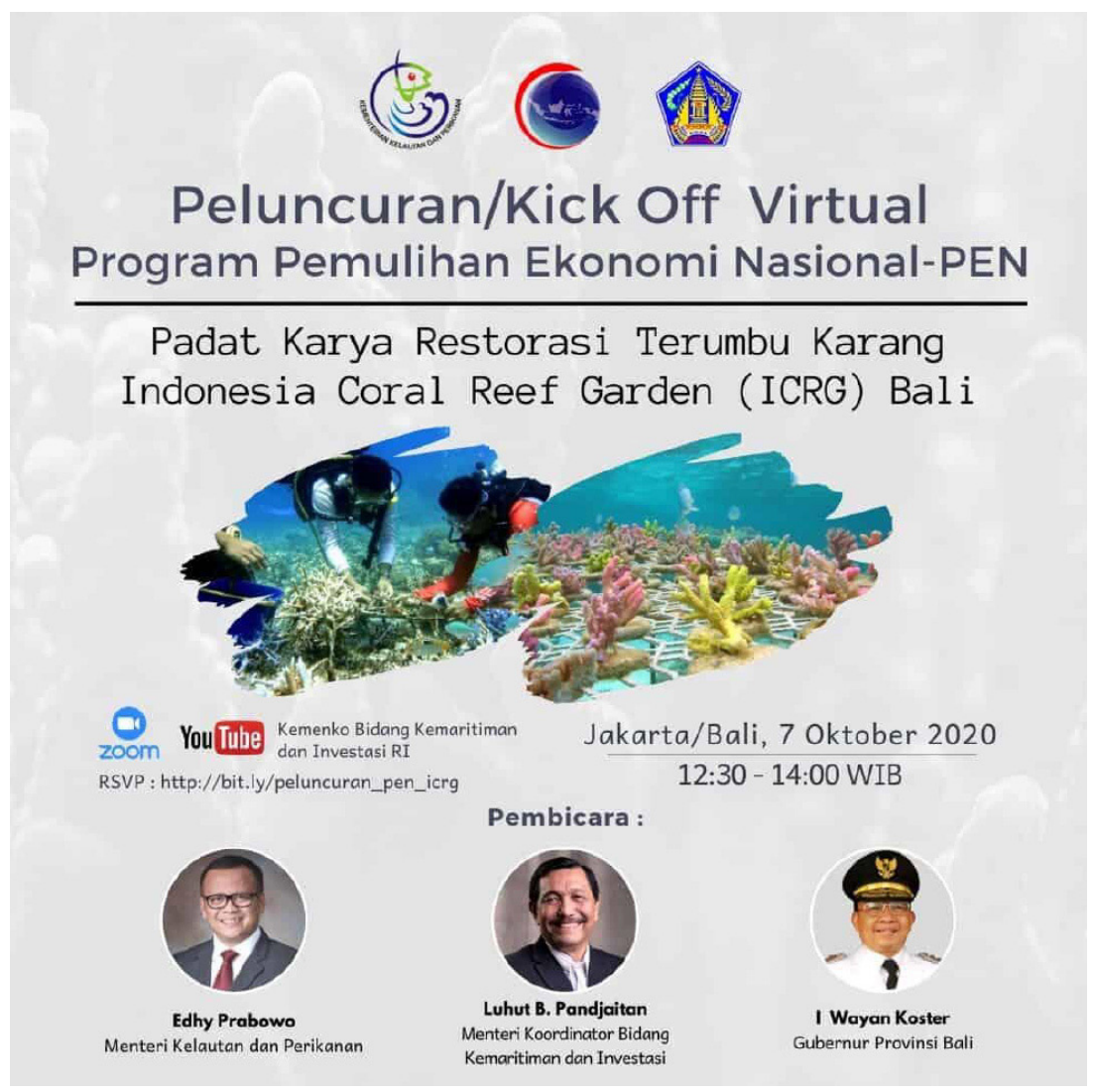

Figure 4. National Economic Recovery (PEN) program for Indonesia Coral Reef Garden (ICRG) Bali Promotional Flyer ${ }^{18}$
Continuous observation and the threat of bleaching. Maintenance and monitoring must be continuing; thus, the newly grown corals may survive. ${ }^{16}$

Some prominent environmental activists at four coral restoration points on Bali's island, namely the Nusa Dua Reef Foundation, the Karang Lestari Foundation, the LINI Foundation, and the Tulamben Dive Guides Organization (OPST), explained their difficulties in executing the conservation program. The interview provided an overview of the multiple challenges they face on conservation during the pandemic. OPST activists in Karangasem Regency expressed since activity restrictions began in March, their members had not been able to dive, observe, and maintain their coral transplantation structures at several dive points. At the same time, there have been alarming reports of bleaching at some points. Even though the diving activity and coral damage were nil, the seawater temperature reached 30 to 31 degrees Celsius. Other problems have been seen on the surface, such as debris, sedimentation from the mountain carried by rain between January to February.

On the coast of Pemuteran Buleleng, Karang Lestari Foundation's biorock program experienced significant difficulties due to the tourism business idle. The biorock program is an integrated conservation program with underwater ecotourism activities. Further, it is reported numerous visible bleachings on corals. The local marine patrol Pecalang Laut activities are also on hiatus due to low operational costs. Meanwhile, monitoring results from LINI Foundation in Les Village, Tejakula, Buleleng Regency, informed that sedimentation did not significantly affect coral during the rainy season. Fish populations were fluctuating depends on the weather. Minor bleaching was reported due to seawater temperature reached 31 degrees from December to January. LINI also reported positive feedback that From August to April 2020, naturally grown corals have grown in the observation cluster.

From the Southern part of Bali, Nusa Dua Reef conservation urged the availability of healthy coral seeds to support future restoration. They also required support from hotel entrepreneurs around the Nusa Dua coast for sustainable funding. Here, twenty-eight species of coral transplanted from eight genera, namely Acroporasp, Pocillopporasp, Turbinariasp, Psammocorasp, Stylophora sp, Echinopora sp, Favites sp, and Montipora sp. While for restoration spots, they are located in front of The St. Regis Bali Resort with 271 reef stars structure, containing 4065 coral seed fragments. Next in front of the Sofitel Bali Nusa Dua with 841 structures consisting of 12,615 coral seedlings in a $600 \mathrm{~m} 2$ area. $^{4}$ 


\section{INDONESIA CORAL REEF GARDEN PROGRAM}

Albeit challenges in coral conservation became a daunting task in 2020, Good news came from Luhut Binsar Pandjaitan, the Coordinating Minister for Maritime Affairs and Investment. He revealed the central Government had compiled a National Economic Recovery (PEN) program for Indonesia Coral Reef Garden (ICRG) Bali. The program is coral reef restoration activities centered in Nusa Dua and several other areas such as Sanur, Serangan, Pandawa Beach, and Buleleng. Luhut claimed the program will be the most massive restoration activity ever in the country. The Government expects labor-intensive restoration activity to overcome the coral reefs damage and improve Bali's marine tourism. Due to coral reef damage in Indonesia, He requested all existing restoration methods to be applied in Nusa Dua, Bali's waters. Later, the area has opted as the center for coral reef restoration in Indonesia. The program is said to have cooperated with the US government and NOAA to make ICRG Nusa Dua a world-class coral reef restoration center. The coordinator minister argued that human activities do not always cause damage to coral reefs. Commonly, the damage caused by pollution, illegal fishing methods, and global warming led to Coral Bleaching. He added, professional green management that involves all parties, both Government and non-government, is necessary to make the conservation run sustainably. ${ }^{19}$

Marine Affairs and Fisheries minister, Edhy Prabowo claimed that the ICRG would not only be used as a tourist spot. The project may act as an education research center. The coral reef garden will be built using the Ministry of Marine Affairs and Fisheries National Economic Recovery fund worth IDR 111.2 billion. The fund will be used to build a fifty hectares coral plantation. Furthermore, the Governor of Bali, I Wayan Koster, expressed his appreciation toward the program. He explained he never thought of such an idea during his two years of duty. Therefore, he was grateful that Bali received the opportunity to be the central government project. Koster believed the program would significantly impact the community, especially in supporting economic recovery since the national economic recovery activities will involve more than 11,000 workers. Due to such a great honor, Koster ensured that the Bali Regional Government would protect the program and its coral reef garden. Through the National program, Koster admitted to enriching his view regarding marine resources that have not been adequately mapped and maintained. ${ }^{20}$

\section{CONCLUSION}

Bali's water's tourism activities have sharply dipped between early to mid-2020, yet it did not stop the coral bleaching phenomenon. The phenomenon is occurring due to water temperature rise. Furthermore, the Government's decision to restrict public activity made the conservation task impossible to be done. Albeit challenges in coral conservation became a daunting task in 2020, pleasant news also came from the central Government. Coordinating Minister for Maritime Affairs and Investment Luhut Binsar Pandjaitan revealed the central Government had compiled a National Economic Recovery (PEN) program for Indonesia Coral Reef Garden (ICRG) Bali. The program is coral reef restoration activities centered in Nusa Dua and several other areas such as Sanur, Serangan, Pandawa Beach, and Buleleng. The coral reef garden will be built using the Ministry of Marine Affairs and Fisheries National Economic Recovery fund worth IDR 111.2 billion. The fund will be used to build a 50 hectares coral plantation. Meanwhile, the Governor of Bali, I Wayan Koster, expressed his appreciation toward the program. Koster believed the program would significantly impact the community, especially in supporting economic recovery since the national economic recovery activities will involve more than 11,000 workers.

\section{REFERENCES:}

1. OR Simarangkir, F Yulianda, M Boer. Pemulihan komunitas karang keras pasca pemutihan karang di Amed Bali. Jurnal Ilmu Pertanian Indonesia, 2015, 20.2: 158-163.

2. R Hasan. Coral Bleaching Ancam Terumbu Karang Bali. Tempo. 2016. Available at URL: https://nasional.tempo.co/ read/778028/coral-bleaching-ancam-terumbu-karang-bali

3. L hancock. Everything You Need to Know about Coral Bleaching-And How We Can Stop It. Worldwildlife[dot] org. 2020. Available at URL: Everything You Need to Know about Coral Bleaching-And How .... https://www. worldwildlife.org/pages/everything-you-need-to-knowabout-coral-bleaching-and-how-we-can-stop-it

4. LD Suriyani. Begini Tantangan Konservasi Terumbu Karang di Saat Pandemi. Mongabay. 2020. Available at URL: https://www.mongabay.co.id/2020/05/11/beginitantangan-konservasi-terumbu-karang-saat-pandemi/

5. Image from AE Agustini article 'Pantai Kuta Sepi, Jalanan Lengang'. Bali tribune. 2020. Available at URL: https:// balitribune.co.id/content/pantai-kuta-sepi-jalananlengang

6. Castro P \& Huber ME. Marine Biology Ed ke-5. New York: Mc Graw Hill International. 2005. Page 119-125

7. RA Hutagalung. Ekologi Dasar. Grafindo: Jakarta, 2010.

8. What is Ocean Acidification?. Official Website of PMEL Carbon program. 2020. Available at URL: https://www. pmel.noaa.gov/co2/story/What+is+Ocean+Acidification

9. I Rosidin. 55 Ribu Hektar Terumbu Karang di Bali Bakal Dikonservasi Tahun 2020. IDN Times. 2018. Available at 
URL: https://bali.idntimes.com/news/bali/imamrosidin/ terumbu-karang-di-bali/3

10. GE Walters, et al. Bottom trawl survey of the eastern Bering Sea continental shelf. 1998. Page 201-203.

11. Nybakken JW. 1986. Readings in marine ecology. Ed.2. Page.289-291.

12. AM Giyanto, et al. Status terumbu karang Indonesia 2017. Jakarta, S., Ed, 2017.

13. NPE Wiratmini. Hanya 55\% Terumbu Karang di Bali Berkualitas Baik. Bisnis[dot]com. 2018. Available at URL: https://bali.bisnis.com/read/20181029/537/854154/hanya55-terumbu-karang-di-bali-berkualitas-baik

14. Image taken from Coral Reef Ecology and SCUBA Diving Channel' Coral Bleaching in Bali 2016 HR'. Youtube. 2016. Available at URL: https://www.youtube.com/ watch?v=yxOfLTnPSUo

15. INMuliarta.CoralBleachingMeluas, RusakTerumbuKarang di Bali. Berita Bali. 2016. Available at URL: https://www. news.beritabali.com/read/2016/03/23/201603230002/ coral-bleaching-meluas-rusak-terumbu-karang-di-bali

16. A Wisuda. Sisi Positif Wabah Corona Bagi Terumbu Karang Indonesia. Mongabay. 2020. Available at URL: https://www. mongabay.co.id/2020/06/01/sisi-positif-wabah-coronabagi-terumbu-karang-indonesia/

17. Infographic Image from beachapedia 'Coral Bleaching'. beachapedia[dot]org. 2019. Available at URL: http://www. beachapedia.org/Coral_Bleaching
18. Image by Biro Komunikasi Kementerian Koordinator Bidang Kemaritiman dan Investasi 'Luncurkan PENICRG, Menko Luhut: Bantu Perekonomian di Bali Akibat Covid-19'. Coordinating Ministry for Maritime Affairs and Investment Official Website.2020. Available at URL: https://maritim.go.id/luncurkan-pen-icrg-menko-luhutbantu-perekonomian-bali-akibat/

19. AM Karunia. Luhut Sebut Restorasi Terumbu Karang Seluas 50 Hektar Butuh Rp 115 Miliar. Kompas[dot] com. 2020. Available at URL: https://money.kompas. com/read/2020/09/24/212339826/luhut-sebut-restorasiterumbu-karang-seluas-50-hektar-butuh-rp-115-miliar.

20. MC Anwar. RI Bangun Kebun Karang Bawah Laut 'Raksasa' Rp111 M di Bali. CNBC. 2020. Available at URL: https://www.cnbcindonesia.com/news/202010071420274-192522/ri-bangun-kebun-karang-bawah-laut-raksasarp111-m-di-bali

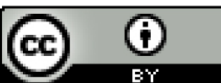

This work is licensed under a Creative Commons Attribution 